\title{
TOWARDS A POLICY FOR EDUCATION
}

$\mathrm{T}$ HE debate on education in the House of Commons on January 27 and that on the Newsom Report on education in the House of Lords on January 29 had much in common, ranging freely over issues raised by the Crowther Report and the Robbins Report as well as by the Newsom Report. That in the House of Commons was opaned by Mr. F. Willey, who commented on the existence of 107 vacancies this year at the colleges of advanced technology, 427 vacancies in courses for the Diploma in Technology and 212 vacancies in courses of degree standard. He urged the need to devote far more resources to research into teaching techniques and tsaching methods and finally stressed the importance to industry of the craftsman and technician. The Minister of Education, Sir Edward Boyle, who followed, pointed out that in maintained secondary schools as a whole the number of pupils of fifteen and over had risen from 250,000 in 1956 to more than 500,000 in 1963 , of whom 130,000 were in secondary modern schools. Britain's expenditure per capita on secondary education had risen by 30 per cent in ten years and since the Second World War about $£ 1,000$ million of major school building projects and minor works had started, while some $£ 200$ million worth of new major school-building projects would be announced in the coming months. As regards teacher training colleges, in which 80,000 places would be available in six years from now, only 290 acceptable candidates failed to secure one of the 21,000 vacancies this year, compared with 815 in the previous year, and the evidence of the Kelsall Report suggested that about half the trained women graduates and three-fifths of the non-graduates with general teaching training would eventually return to teaching after an average absence of nine years.

Sir Edward then announced the Government's intention to raise the school-leaving age to sixteen in the educational year 1970-71. He said that the Government was satisfied that the supply of teachers was likely to be significantly better by 1970 , that the necessary buildings could be provided in time without affecting building programmes already announced, and that there would be adequate time for the necessary arrangements. By 1970 , if the present national trend continued, 40 per cent of secondary school pupils would be staying on voluntarily to the age of sixteen, but this would be very unevenly spread as between different areas. If all five-year courses in secondary schools remained optional, whether a boy or girl took advantage of the option was likely to depend on his family and neighbourhood tradition. Sir Edward believed that there was still a danger of underrating the particular abilities of many children and that accordingly the case for compulsion and setting a target date was inescapable. He explained that the Government had decided on a date two years later than that recommended by the Newsom Report partly because Britain's present efforts to increase the supply of teachers would still leave her 35,000 short by 1970 of what would be needed to achieve a desirable staffing standard, while to raise the school-leaving age in 1970-71 would require about 20,000 extra teachers. Any earlier raising of the school-leaving age must increase the severity and the duration of the initial setback in staffing standards. He hoped that the announcement would both increase the flow of graduates to the schools and also the return of women teachers. On present estimates the effect of raising the school-leaving age to sixteen would be to increase the school population by about 350,000 from September 1971. A substantial school building programme would be necessary and this should be possible without disturbing the programmes for 1965-68. The plans already announced for improving primary education would not be affected.

On the implications for the curriculum, Sir Edward said that the additional pupils would fall broadly into two categories: those comparable in ability with many who are already staying on voluntarily; and those in a low category of ability for whom five-year courses were still almost unknown. Much constructive thought was already being given to the best kind of five-year course for the non-academic ehild, and Sir Edward, like many other speakers in both Housas, pointed out that the Newsom Report had emphasized that the standard indicated by average was rising all the time. The working party appointed in July under Sir John Lockwood to deal with school curricula and examinations was expected to report in March, and the volume of educational research supported by the Ministry was increasing steadily. Projects to the value of more than $£ 250,000$ already supported cover the nature of the learning process, experiments with the initial teaching alphabet, the educational treatment of handicapped children, problems of grammar schools associated with different social backgrounds, and projects in further education and teacher training. Turning from secondary education, on which over the next five years Britain would be spending an extra $£ 250$ million, Sir Edward said that expenditure on education in this Parliament had already risen from $£ 120$ million a year to $£ 275$ million, before the Government's decision had been to spend $£ 3,500$ million on higher education over ten years. Contact had already been established between the colleges of advanced technology and the University Grants Committee, and it was agreed that the first essential was the appointment by the governing bodies, in consultation with that Committee, of academic advisory committees for each of the ten colleges. For the moment, the Ministry of Education was still responsible for the affairs of the colleges, but it was acting in close co-operation with the University Grants Committee. Sir Edward said he had already invited the colleges of advanced tochnology to discuss how best they could contribute to the target of 19,000 students set by the Robbins Report for 1967-68, and he hoped shortly to announce revised targets and figures for building starts for 1964-66. He also referred to the contribution of the technical colleges and said that he expected shortly to receive the HennikerHeaton Report on day release.

The Government had not yet reached a conclusion on the recommendations of the Robbins Committee concerning teacher training, but Sir Edward assured the House that all the necessary work was in hand to meet the short-term target for expansion. The total building programme for 1964-67 of more than $£ 20$ million for the training colleges was not being held up, and the fact that no final decision had yet been reached about the future structure of Government did not mean that there would be any delay in implementing tho Robbins recommendation for expanding higher education.

In replying on this debate the Minister for Science, Mr. Q. Hogg, announced that the 1964-65 Estimates would include provision for 2500 postgraduate awards of the Department of Scientific and Industrial Research, an increase of 25 per cent on the current year, and 1,000 awards in the humanities, as against less than 500 . In accepting the advice of the University Grants Committee on the recommendation of the Robbins Committee for a further university in Scotland, in addition to the University of Strathclyde, the Government had asked the 
University Grants Committee to advise further on the choice of a location. He indicated that decision regarding the structure of Government would be taken within a weok or two, and in reply to questions on the following day regarding the recommendation for establishing six new universities, Mr. Hogg said the whole matter had been referred to the University Grants Committee. He also gave the figures for medical students registered at universities as follows: $1959,12,314 ; 1960,12,276 ; 1961$, 12,$254 ; 1962,12,550 ; 1963,12,890$.

In opening the debate in the House of Lords, Lord Silkin referred to the recognition in the White Paper on Industrial Training that the number of new entrants to skilled occupations was insufficient for Britain's future needs, and also to the importance of securing the right quality of teachers and teachers of the right status. The Earl of Dundee, who followed, for the Government, apart from a closer review of the Newsom Report, addod little to what Sir Edward Boyle had already said in the House of Commons. He pointed out that Britain's expenditure of $£ 414$ million on education in 1952 was just more than 3 per cent of her gross national product; $£ 804$ million in 1958-59 was 4 per cent; and the $£ 1,300$ million in the present year was 5 per cent of her gross national product. Later, the Earl of Bessborough referred to educational television, expressing the hope that this medium would be used to the maximum extent possible for educational purposes. He thought that ultimately it might be necessary for one or more channels to be devoted exclusively to education.

\section{SCIENTIFIC RESEARCH IN SCHOOLS}

$\mathrm{T}$ THE question of teachers in schools undertaking research in science brings together a number of considerations which are nicely poised. One primary fact is that any research with a successful outcome is a contribution to the total stock of human knowledge. But many teachers can be good instructors even if they have nothing to do with research, provided that they take the trouble to keep themselves informed of new developments. They are not all capable of worth-while independent enquiry, and the courses they pursued before graduation may have fallen short of making then, familiar with the spirit and techniques of experimental investigation. From this point of view the teachers most likely to succeed in research are those who after graduation stayed on for some time at the university, and then, perhaps finding prospects not up to expectations, took up appointments in schools. In the opposite direction, there is always a small movement of teachers who after a period of school experience return to university work.

Then there are different kinds of research which teachers can take up. Some are worth pursuing, although they do not carry enquiry very far; they can be 'pottered' with as occasions permit; they need not make any heavy demands on attention and may be looked on almost as a recreation. A.t the other extreme are research problems which take a big slice of a teacher's free time and mental energy. Indeed, it does not necessarily follow that a man who is competent at research is a good instructor, well versed in all sections of the sixth-form syllabus which ho is required to teach. The project which he is pursuing may have scarcely any relation to his school work. Again, in so far as research constitutes an important element in his life, it may draw him away from the corporate life of the school, lower his social standing among members of the local community and debar him from higher educa- tional posts. Typically, what he can hope for is to become head of his own department.

Among considerations of this nature the point of equipoise is slowly shifting, and mainly through help from the Royal Society an increasing number of science teachers are carrying out research. In 1957, taking the view that "the teaching of science in schools might be improved if those engaged in it were enabled to carry out some research work of their own choice, preferably involving participation by pupils", the Society set up a Scientific Research in Schools Committee. This Committee invites proposals from any teacher about a research project which he or she would like to carry out. If this meets with approval, the Committee appoints a suitable adviserusually a Fellow of the Society or a senior member of a university department-with whom the teacher can keep in contact. The Committee is also prepared to consider applications for grants for the purchase of such materials and apparatus as may be required.

The sixth annual report of the Committee, which was issued in November 1963, shows that 84 science teachers were carrying out research with the help of the Royal Society, and that six original papers had, during 1963 , been published. However, figures received more recently from the Royal Society indicate that by mid-January 1964, 94 science teachers are now participating in the scheme. The təachers concerned hold appointments in a wide range of schools: Secondary Modern, 4; Secondary Grammar, 42; Public and Private, 34; and others, 5. The spread of the subjects covered was: biology, 43; chemistry, 24; crystallography, 2; engineering, 1; geology, 6; physics, 14; radio-astronomy, 3 ; and time and motion study, 1. The grants supplied by the Royal Society for these projects totalled $£ 619$ in $1957-58$, while the figure for the year $1962-63$ was $£ 4,450$.

\section{THE BRITISH ANTARCTIC SURVEY}

$\mathrm{T}$ HE British Antarctic Survey Bulletin* is intended to supplement the existing series of monographs, the British Antarctic Survey Scientific Reports, by providing a channel of publications for preliminary reports, short notes and papers including some which are not specifically scientific. The Bulletin, which is being edited by Dr. R. J. Adio and Miss E. Todd, will be published as necessary to cope with the flow of papers, probably two or three times each year.

The first two issues, June 1963 (pp. 54) and December 1963 (pp. 96), show that these objectives are being met.

\footnotetext{
- British Antarctic Survey. Bulletin, No. 1; June 1963. Pp. 1-54. (London: British Antarctic Survey, 1963.) 10s. net.
}

These issues contain four papers on biological subjects, three on glaciology, two on meteorology, two on geophysical surveys and one on geomorphology. "The Human Element in Polar Exploration", by Sir Vivian Fuchs, and the longest paper of 25 pages on "Polar Ships and Navigation in the Antarctic", by J. P. Morley, are more general papers of considerable interest. Summaries of four recent "British Antarctic Survey Scientific Reports" are given in the first issue, and the foreword indicates that correspondenco concerning papers may appear in the future.

The Bulletin is printed on art paper and is copiously illustrated by photographs, maps, line drawings, etc. The quality and interest of the scientific papers are similar to 